\title{
NĚKOLIK POZNÁMEK K HIERARCHII SPOLEČENSKÝCH SYSTÉMU゚
}

\section{SOME REMARKS TO HIERARCHY OF SOCIAL SYSTEMS}

\section{DOC. RNDR. MiLAN VITURKA, CSC.}

\author{
ING. VILÉM PAŘIL \\ Katedra regionální ekonomie a správy $\mid$ Depart. of Regional economics and Administration \\ Ekonomicko-správni fakulta Faculty of Economics and Public Administration \\ Masarykova univerzita Masaryk University \\ $\triangle$ Lipová 41 a, 60200 Brno, Czech Republic \\ E-mail:viturka@econ.muni.cz,vilem@mail.muni.cz
}

\begin{abstract}
Anotace
Př́spěvek se zabývá prostorovými aspekty hierarchického uspořdáni společenských systémů. V tomto ohledu je hlavni pozornost zaměřna na mikroregionálni úroveñ, která byla dále analyzována na přikladu České republiky. Zejména byla identifikována mikroregionálni centra nesplňujici své centrálni funkce (zejména pracovni a dále vzdélávaci funkce). Pro experimentálni modelováni pracovnich interakci pak byl využit teoretický koncept mezni miry mobility výrobnich zdrojü. Př́slušná prrípadová studie byla zaměřna na hodnoceni mezni míry mobility pracovni síly ve spádové oblasti krajského města Brna, která byla vymezena obcemi zahrnutými do Integrovaného dopravního systému Jihomoravského kraje. Tyto obce byly rozdèleny do sedmi vzdálenostnich pásem, pro které byla určena mezni míra mobility v souladu s potenciálním navýšením přijmů v prípadě vyjižd'ky za praci do Brna.
\end{abstract}

\section{Klíčová slova}

hierarchie, integrace, mobilita.

\section{Annotation}

The paper deals with the spatial aspects of a hierarchical arrangement of social systems. In this respect, the main attention is focused on the micro-regional level, which has been further analysed on the example of the Czech Republic. In particular, the identification of micro-regional centres not fulfilling their central functions (especially the working and further educational functions) was carried out. For experimental modelling of interactions was used the theoretical concept of marginal rate of mobility of production resources. Corresponding case study was focused on evaluation of the marginal rate of the mobility of workforce within the catchment area of regional capital town Brno, which has been defined by the municipalities included in the integrated transport system of the South Moravian region. These municipalities were divided to seven distance zones and consequently marginal mobility rate has been calculated according to expected potential revenue increase with assumption of job commuting to Brno.

Key words

hierarchy, integration, mobility. 


\section{1. Úvod}

Vývojová diferenciace vysoce rozvinutých společenských systémů je logicky úzce propojena s jejich hierarchickou diferenciací. Tyto všeobecné evoluční procesy determinují prostorové uspořádání společenských systémů. Konkrétní podoba tohoto prostorového uspořádání je pak utvářena zejména působením specifických procesů polarizace a integrace. Prezentace dosažených výsledků výzkumu těchto procesů pak tvoří hlavní cíl tohoto příspěvku.

V souladu s výsledky vlastního dlouhodobého výzkumu (Viturka, 2010) lze konstatovat, že zatímco vznik a dynamika pólů rozvoje jako hlavních nositelů polarizace je především výsledkem přirozeného historického vývoje (pokusy o iniciaci vzniku nových pólů rozvoje nebyly obvykle prŕliš úspěšné), pak podpora tvorby rozvojových os jako hlavních nositelů integrace představuje významnou př́ležitost pro efektivní orientaci regionální politiky ${ }^{1}$. Podpora šíření rozvojových efektů, generovaných v dominantní míře póly rozvoje, totiž umožňuje úspěšně překonávat územní rozvojové limity odvíjející se od nedostatečné nabídky či naopak př́lišného využivání výrobních zdrojů. Konkrétní zaměření programů podpory je ovšem v souladu s funkční komplexitou společenských systémů nezbytné přizpůsobit profilujícím typům územních interakcí odpovídajících jednotlivým hierarchickým úrovním. Celkově lze konstatovat, že integrační procesy přispívají ke snižování regionálních disparit na všech hierarchických úrovních a vdlouhodobém horizontu tak zvyšují regionální konkurenceschopnost. Na základě disponibilních poznatků, verifikovaných vlastními analýzami zahrnujícími kromě České republiky i 10 nových středoevropských a východoevropských členských zemí EU (Viturka et al., 2011), byl vytvořen dynamický koncept hierarchického uspořádání společenských systémů, jehož základní komponenty jsou zachyceny $\mathrm{v}$ tabulce 1 . Podle tohoto konceptu se na mikroregionální úrovni projevuje jako profilující typ interakcí dojížd'ka do zaměstnání a socioekonomická integrace je zde tedy úzce spojená s tvorbou regionálních pracovních trhů integrace na bázi pracovních interakcí. Na vyšších hierarchických úrovních je pak integrace spojena s následujícími profilujícími interakcemi: mezoregionální úroveň - integrace na bázi produkčních interakcí, makroregionální úroveň - integrace na bázi řídích interakcí a nadnárodní resp. globální úroveň - integrace na bázi obchodních interakcí.

Tab. 1: Hierarchické uspořádání společenských systémů

\begin{tabular}{|l|l|l|l|l|}
\hline $\begin{array}{l}\text { hierarchická } \\
\text { úroveň }\end{array}$ & $\begin{array}{l}\text { hlavní nositelé } \\
\text { polarizace }\end{array}$ & $\begin{array}{l}\text { hlavní nositelé } \\
\text { integrace }\end{array}$ & $\begin{array}{l}\text { hlavní typy } \\
\text { interakcí }\end{array}$ & kličové struktury \\
\hline mikroregionálni & nodální centra & $\begin{array}{l}\text { vztahy centra s } \\
\text { okolními obcemi }\end{array}$ & pracovní & $\begin{array}{l}\text { zaměstnavatelé, } \\
\text { zaměstnanci }\end{array}$ \\
\hline mezoregionálni & $\begin{array}{l}\text { póly rozvoje národního } \\
\text { významu }\end{array}$ & $\begin{array}{l}\text { rozvojové osy } \\
\text { regionálního významu }\end{array}$ & produkční & $\begin{array}{l}\text { velké firmy, } \\
\text { územní správa }\end{array}$ \\
\hline makroregionální & $\begin{array}{l}\text { póly rozvoje } \\
\text { nadnárodního významu }\end{array}$ & $\begin{array}{l}\text { rozvojové osy } \\
\text { národního významu }\end{array}$ & ř́íící & $\begin{array}{l}\text { ústředí velkých } \\
\text { firem, státní správa }\end{array}$ \\
\hline globálni & $\begin{array}{l}\text { póly rozvoje globálního } \\
\text { významu }\end{array}$ & $\begin{array}{l}\text { rozvojové osy } \\
\text { nadnárodního významu }\end{array}$ & obchodní & $\begin{array}{l}\text { TNC, mezinárodní } \\
\text { společenství }\end{array}$ \\
\hline
\end{tabular}

Poznámka: TNC = nadnárodní firmy (transnational corporations).

Zdroj: vlastní výzkum.

Ze širšího teoretického pohledu lze ve výše uvedeném kontextu upozornit na skutečnost, že aplikace vytvořeného konceptu hierarchického uspořádání společenských systémů výrazně zvyšuje vypovídací schopnosti věcně korespondující teorie centrálních míst, zejména pokud jde o dynamické aspekty rozvoje sídelních systémů v intencích teorie tržních zón A. Lösche (rozšiřující původní Christallerovu teorii o adekvátní vlivy průmyslových aktivit). $\mathrm{V}$ tomto směru je zvláště př́nosná originální metoda vymezení rozvojových os na základě komparativních hodnot kvality podnikatelského prostředí což

\footnotetext{
${ }^{1} \mathrm{~K}$ tomu je účelné poznamenat, že významová pozice zejména hlavních měst a v menší míře i dalších významných sídelních center se obecně vyznačují silnou inercií (např. v České republice byla současná podoba základní urbanistické struktury zformována již koncem 19. století).
} 
výrazně kontrastuje s pouze teoretizovanými soustavami prostorových výsečí v teorii tržních zón (jak rozvojové osy, tak prostorové výseče mají svůj počátek v centrech vyššího řádu). V této souvislosti je užitečné upozornit na skutečnost, že u průmyslových firem hrají, na rozdíl od firem působících v terciálních odvětvích, významnější roli lokalizační než urbanistické úspory (jejichž pozitivní vlivy jsou navíc u velkých měst často negovány urbanistickými ztrátami, např. dopravním přetížením). Aplikace vypracovaného konceptu pak ve srovnání s výrazně statickou teorií centrálních míst umožňuje vytvořit mnohem realističtější (a tedy i prakticky př́ínosnější) modely regionálního rozvoje.

\section{Diskuse vybraných otázek včetně generalizace empirických poznatků}

V této kapitole je naše pozornost koncentrována především na mikroregionální úroveň prostorového uspořádání společenských systémů. Tuto úroveň obecně představují tzv. nodální regiony, pro které je charakteristická polarita typu centrum - zázemí. Nodální regiony představují primární regionální úroveň prostorového uspořádání (a tedy $\mathrm{i}$ aplikace metody regionalizace), v jejímž rámci jsou prostřednictvím dojížd'kových procesů řešeny dlouhodobé územní nerovnováhy vznikající na úrovni jednotlivých obcí (uvedené procesy jsou všeobecně považovány za hlavní nástroj vnitřní integrace nodálních regionů). V tomto směru pak jde především o existující nerovnováhy mezi obytnými a pracovními funkcemi obcí a dále o nerovnováhy mezi obytnými a obslužnými funkcemi obcí, které se týkají zejména vzdělávacích a dále zdravotnických služeb. $Z$ pohledu aktuálního diskurzu vedeného $\mathrm{v}$ oblasti regionálního rozvoje pak lze poukázat na zajímavý závěr (Mulligan et al., 2012), podle kterého má geografická blízkost a jí primárně podmíněné procesy (zvláště pokud jde o procesy hospodářské spolupráce) větší význam pro ekonomický růst jednotlivých obcí než tržní potenciál dané lokality.

V př́ipadě České republiky je možné nodální regiony resp. mikroregiony podmíněně ztotožnit $\mathrm{s}$ vymezenými administrativními regiony tzv. pověřených obcí s rozšířenou působností 3 . stupně ORP (Hampl, 2005). K tomu je ovšem potřebné poznamenat, že některé ORP, které jsou ve výše uvedeném kontextu obecně považovány za nodální centra, mohou během svého vývoje postupně ztrácet některé své centrální (střediskové) funkce. Hlavním důvodem je zde obvykle konkurence silnějších nodálních center nacházejících se v jejich nejbližším sousedství. Dalším důvodem je pak i skutečnost, že některá ORP byla pro výkon řady centrálních funkcí předem diskvalifikována jejich nedostatečnou velikostí (jde o regiony ORP, které byly ustanoveny především z praktického důvodu co nejrovnoměrnějšího pokrytí venkovských oblastí). Celkově lze konstatovat, že odpovídající střediskové pracovní funkce v podmínkách České republiky nevykonává přibližně jedna třetina ORP a podobný podíl pak zaujímají i ORP ztrácející své střediskové vzdělávací funkce $\mathrm{z}$ důvodu nedostatečně rozvinuté př́íp. neefektivně využité infrastruktury středních škol (absolutní a relativní podíly těchto ORP jsou prezentovány $\mathrm{v}$ následující tabulce). $\mathrm{K}$ tomu je potřebné poznamenat, že potenciální vlivy na výkon střediskových funkcí indukované dlouhodobým ekonomickým rozvojem je možné identifikovat pomocí srovnání výsledků podrobných strukturovaných šetření o dojížd’ce (zejména srovnání obou posledních sčítání obyvatelstva z let 2001 a 2011) nebo pomocí hodnocení změn v regionální kvalitě podnikatelského prostředí (Viturka, 2011).

Z tabulky uvedené níže vyplývá, že z celkem 205 ORP existujících v České republice ztrácejí centrální pracovní funkce především nodální centra nacházející se v blízkém zázemí největších měst, tedy Prahy, Brna, Ostravy (pouze v tomto př́padě se mezi nimi nacházejí i větší satelitní centra) a Plzně, následovaná skupinou nejmenších center ustanovených $\mathrm{v}$ rámci provedené reformy územní správy od 1. ledna 2003. Z uvedených informací pak na druhé straně vyplývá, že většina ORP (více než $70 \%$ ) plní své pracovní funkce, což potvrzuje jejich zásadní význam pro ekonomický a sociální rozvoj mikroregionů. $\mathrm{V}$ tomto kontextu mají préedevším pozitivní vlivy na úroveň zaměstnanosti a př́ijmů obyvatelstva trvale bydlícího v pracovně závislých obcích (z dalších pozitivních vlivů lze uvést např. potenciální možnosti využití dovedností a znalosti získaných v místě pracoviště pro zvýšení podnikatelské aktivity $\mathrm{v}$ místě trvalého bydliště). Podobné závěry pak lze učinit $\mathrm{i} \mathrm{v}$ př́ípadě vzdělávacích funkcí zajištovaných v ORP (určitou odlišností od předchozího př́padu je zjištěná extrémně vysoká míra ORP nezajištujuících tuto střediskovou funkci v Plzeňském kraji). $Z$ obecného pohledu pak nepochybně platí, že postavení jednotlivých městských i venkovských obcí v rámci územní dělby práce má významné vlivy nejen na jejich ekonomický rozvoj, ale i na jejich sociální 
rozvoj včetně př́slušných demografických charakteristik (např̀. často pozorovaným důsledkem periferní polohy zejména menších obcí z pohledu dlouhého časového horizontu je emigrace mladšího a vzdělanějšího obyvatelstva, což pochopitelně podvazuje perspektivní možnosti jejich dalšího rozvoje).

Tab. 2: ORP nenaplňující své centrální funkce

\begin{tabular}{|l|c|c|c|c|c|}
\hline \multirow{2}{*}{ kraj } & regiony & \multicolumn{2}{c|}{ pracovní funkce } & \multicolumn{2}{c|}{ vzdělávací funkce } \\
\cline { 3 - 6 } & ORP & počet & \% podíl & počet & $\%$ podíl \\
\hline Středočeský & 26 & 8 & 31 & 7 & 27 \\
\hline Jihočeský & 17 & 5 & 29 & 3 & 18 \\
\hline Plzeňský & 15 & 8 & 53 & 10 & 67 \\
\hline Karlovarský & 7 & 2 & 29 & 2 & 29 \\
\hline Ústecký & 16 & 0 & 0 & 2 & 13 \\
\hline Liberecký & 10 & 1 & 10 & 3 & 30 \\
\hline Královéhradecký & 15 & 1 & 7 & 4 & 27 \\
\hline Pardubický & 15 & 2 & 13 & 4 & 27 \\
\hline Vysočina & 15 & 5 & 33 & 5 & 33 \\
\hline Jihomoravský & 21 & 10 & 48 & 8 & 38 \\
\hline Olomoucký & 13 & 3 & 23 & 3 & 23 \\
\hline Zlínský & 13 & 3 & 23 & 2 & 15 \\
\hline Moravskoslezský & 22 & 12 & 55 & 8 & 36 \\
\hline Česká republika & 205 & 60 & 29 & 61 & 30 \\
\hline
\end{tabular}

Poznámka: Nezahrnut kraj Praha.

Zdroj: vlastní výzkum, Hampl (2005).

Integrační procesy vycházející z pracovních interakcí a jejich dynamika potvrzuje zvyšující se závislost zejména menších sídel na významnějších městech, počínaje plnohodnotnými centry nodálních regionů. V tomto kontextu je potřebné upozornit $\mathrm{i}$ na další významné ekonomické souvislosti např. na skutečnost, že $\mathrm{v}$ případě odvětví $\mathrm{s}$ vyšší přidanou hodnotou má úroveň mezd $\mathrm{v}$ místě produkce na rozdíl od odvětví s nižší přidanou hodnotou pouze malý vliv na celkový odbyt př́slušných výrobků a služeb. Je zřejmé, že výrobky s nižší přidanou hodnotou jsou charakteristické pro venkovské regiony, které nemohou konkurovat městským regionům disponujícím odpovídající nabídkou kvalitní pracovní síly (městské regiony mají i diverzifikovanější strukturu ekonomiky a jsou tedy odolnější vůči negativním vlivům generovaným rostoucí globalizací ekonomiky). V této souvislosti je účelné poukázat na korespondující rozdíly mezi exportně orientovanými resp. bazickými odvětvími (viz teorie exportní báze) a zbývajícími místně orientovanými odvětvími, které logicky vyúst'ují v silnou závislost rozvoje mikroregionů na externí poptávce po zboží a službách v podmínkách otevřené ekonomiky.

Výše uvedené empiricky podložené závěry jsou $\mathrm{v}$ další části testovány $\mathrm{z}$ pohledu teoretického konceptu mezní míry mobility výrobních zdrojů, která determinuje prostorový rozsah integračních procesů. Tuto zřejmou skutečnost lze výstižně ilustrovat na př́kladu dojížd’ky do zaměstnání. Pro účely tohoto výzkumu byla mezní míra mobility pracovních sil do zaměstnání testována na př́íkladu oblasti geograficky vymezené pokrytím integrovaného dopravního systému Jihomoravského kraje (IDS JMK), kde byla uvažována potenciální dojižd’ka obyvatel ze všech obcí do jeho hlavního spádového centra, tedy Brna, vyjma odlehlých částí Jihomoravského kraje, pro které je potenciálním hlavním spádovým centrem Znojmo nebo Hodonín.

Pro výzkum potenciálu přepravní mobility ve výše vymezené oblasti byly využity tři hlavní zdroje dat pro veřejnou dopravu (kombinující dopravu autobusem, vlakem a městskou hromadnou dopravou v Brně) a osobní automobilovou dopravu. Pro oba typy dopravy byl základním východiskem seznam obcí mimo zóny 100 a 101 IDS JMK (které jsou zahrnuty v MHD Brno a pokrývají území města Brna). U veřejné dopravy byl pak jako hlavní zdroj dat pro zjišsění vzdálenosti využit portál 
http://jizdnirady.idnes.cz, dle kterého byla zjištěna vzdálenost dané obce do centra Brna a také celkový čas potřebný na přepravu do centra Brna při využití veřejné dopravy. Zde byl za relevantní považován nejrychlejší dopravní spoj umožňující dopravit se do centra Brna do deseti hodin dopoledne $\mathrm{v}$ pracovní den a za relevantní vzdálenost pak byla považována nejkratší veřejnou dopravou dostupná trasa. Pro automobilovou dopravu byl pak hlavním informačním zdrojem portál http://maps.google.cz, ze kterého byla čerpána data pro osobní automobilovou dopravu. Za relevantní údaje byly v tomto př́ípadě považovány nejkratší dosažitelné spoje.

Dalším významným vstupem do analýzy mobility pracovních sil v určité oblasti jsou samozřejmě informace o nákladech na dopravu. Pro ceny veřejné dopravy byl využit tarifní ceník IDS JMK, který určuje cenu dle počtu zón, přes které se cestující dopravuje do cílového místa. Základním tarifem je sazba pro zóny 100 a 101 (tedy pro MHD Brno). Dále je rozlišeno dalších devět tarifu, vždy s každou další překročenou zónou, prričemž od devíti překročených zón je již cena vždy stejná. Cenový rozsah pro námi vymezenou oblast se tedy pohybuje dle tarifního pásma a způsobu nákupu (možnost koupit měsíční, čtvrtletní či roční tarif) od 830 Kč do 31560 Kč, přičemž kalkulována byla cena roční jízdenky ${ }^{2}$. Pro náklady na osobní automobilovou dopravu byla kalkulována průměrná cena pohonných hmot $36,65 \mathrm{Kč} / 1$ a průměrná spotřeba $71 / 100 \mathrm{~km}$ a dále byla zahrnuta $\mathrm{i}$ tzv. základní sazba vycházející ze zákoníku práce z $§ 157$ odst. 3 a odst. 4, která zohledňuje určité opotřebení automobilu na každý ujetý kilometr a v současnosti jí odpovídá cena $3,80 \mathrm{Kč} / \mathrm{km}{ }^{3}$. Pro určení četnosti jízdy do zaměstnání, a tedy celkového počtu najetých kilometrů za jeden rok (pro možnost srovnání s roční tarifní jízdenkou v př́padě veřejné dopravy) byl použit celkový počet pracovních dní v roce 2012 tj. 252 dní násobený dvěma.

Ve výše vymezené spádové oblasti Brna bylo určeno celkem sedm zón podle vzdálenosti obce do centra, přičemž za určující vzdálenost byla považována nejkratší možná trasa dosažitelná veřejnou nebo automobilovou dopravou (ve většině príípadů se jedná o vzdálenost dosaženou automobilem. Jednotlivé obce pak byly zařazeny do těchto zón bez ohledu na tarifní pásmo IDS JMK. Pro výpočet průměrných ročních nákladů na dopravu je nutné určit strukturu využití typu dopravy pro vyjížd'ku do zaměstnání, kterou zobrazuje následující tabulka.

Tab. 3: Podíl veřejné a individuální dopravy ve vymezených zónách

\begin{tabular}{|c|c|c|}
\hline zóna & individuální & veřejná \\
\hline 0 až 10,0 & 0,19 & 0,81 \\
\hline 10,1 až 20,0 & 0,35 & 0,65 \\
\hline 20,1 až 30,0 & 0,37 & 0,63 \\
\hline 30,1 až 40,0 & 0,30 & 0,70 \\
\hline 40,1 až 50,0 & 0,30 & 0,70 \\
\hline 50,1 až 60,0 & 0,30 & 0,70 \\
\hline 60,1 a více & 0,30 & 0,70 \\
\hline & \multicolumn{2}{|c|}{ Zdroj: Carský (2007); vlastní výpočty. }
\end{tabular}

Mezní míra mobility, resp. dojížd'ková vzdálenost je určována vztahem, který lze zapsat následujícím způsobem:

$$
M m=\frac{P p}{P n},
$$

kde $\mathrm{Mm}=$ mezní míra mobility, $\mathrm{Pp}=$ prrírůstek př́ijmů, $\mathrm{Pn}=$ př́růstek nákladů, který lze dále definovat následujícím vztahem:

\footnotetext{
${ }^{2}$ Viz aktuální ceník IDS JMK dostupný na portálu: http://www.idsjmk.cz/tarif.aspx

${ }^{3}$ Viz ČSÚ (2011): Míra inflace, vývoj spotřebitelských cen vybraných výrobků za rok 2011, a dále vývoj inflace v roce 2012. Pro zjednodušení byla kalkulována průměrná cena nafty a standardního benzínu, přičemž průměr nebyl vážen dle podílu odpovídajících typů motorů na trhu.
} 


$$
P n=\frac{N v(Z v)+N i(Z i)}{Z v+Z i},
$$

kde $\mathrm{Nv}=$ průměrný př́růstek nákladů na veřejnou dopravu, $\mathrm{Zv}=$ podíl veřejné dopravy $\mathrm{v}$ př́slušné zóně, $\mathrm{Ni}=$ průměrný př́růstek nákladů na individuální automobilovou dopravu. $\mathrm{Zi}=$ podíl individuální automobilové dopravy v př́slušné zóně.

Následující tabulka uvádí přehled mezní míry pracovní mobility pro jednotlivé zóny, resp. vzdálenosti bydliště dojíždějících pracovníků do centra Brna. Pro Mm platí, že pokud $\mathrm{Mm}>1$, existuje zde předpoklad pro dosažení ekonomické motivace obyvatel z určité vzdálenosti k dojíždění do spádového centra. Naopak pokud $\mathrm{Mm}<1$, pak se pro pracovní sílu z dané vzdálenosti nevyplatí dojiždět do centra zkoumané spádové oblasti. Při Mm $=1$, resp. při dosažení hodnot blízkých jedné (odchylka do $0,1)$, jde o určité hraniční pásmo, kterého by pro dojíždění do centra bylo nutno zvažovat více faktorů především individuálního charakteru. $\mathrm{V}$ tabulce je kalkulována mezní míra mobility pro pět odlišných situací podle potenciálního přírůstku př́imu vyjíždějícího pracovníka (jsou uvažovány hodnoty na v rozmezí od 1250 až 10 tis. Kč ${ }^{4}$. Vyznačena jsou tři pásma: zeleně je vyznačeno pásmo ekonomické výhodnosti, červeně pásmo ekonomické nevýhodnosti a modře pak pásmo hraniční, kde vyjížd'ka může být uvažována, ale je nutné zahrnout i řadu dalších faktorů, které hrají roli při rozhodování potenciálně obyvatelstva o vyjížd'ce za prací.

Tab. 4: Poměr př́rístku př́immů a nákladi̊ na dojiždění za prací

\begin{tabular}{|c|c|c|c|c|c|}
\hline Zóna/Pp & 1250 & 2500 & 3600 & 5000 & 10000 \\
\hline 0 až 10,0 & 1,30 & 2,61 & 3,75 & 5,21 & 10,42 \\
\hline 10,1 až 20,0 & 0,62 & 1,25 & 1,80 & 2,49 & 4,99 \\
\hline 20,1 až 30,0 & 0,39 & 0,78 & 1,12 & 1,55 & 3,10 \\
\hline 30,1 až 40,0 & 0,34 & 0,68 & 0,98 & 1,36 & 2,72 \\
\hline 40,1 až 50,0 & 0,27 & 0,55 & 0,79 & 1,10 & 2,19 \\
\hline 50,1 až 60,0 & 0,23 & 0,46 & 0,66 & 0,92 & 1,84 \\
\hline 60,1 a více & 0,20 & 0,41 & 0,59 & 0,81 & 1,63 \\
\hline
\end{tabular}

Poznámka: Neuvažována hodnota času ztraceného dopravou ${ }^{5}$.

Zdroj: vlastni výzkum

Jestliže jsou náklady na dojíždění nižší než výnosy, je možným řešením situace migrace nezaměstnaného práceschopného obyvatelstva (podle neoklasické teorie). Migrace pracovních sil vyrovnává její mezní produktivitu pracovní síly v regionu se zmenšující se poptávkou s mezní mírou produktivity $\mathrm{v}$ regionu se zvětšující se poptávkou a následně dojde $\mathrm{k}$ obnovení rovnováhy mezd (ovšem při vzrůstu počtu obyvatel region s předchozím nárůstem poptávky po pracovní síle).

\section{Závěr}

V souladu s teoretickým i empirickým ukotvením výše diskutovaného modelu hierarchického uspořádání společenských systémů je možné přijmout pozitivní závěr o jeho přenositelnosti, zvláště pokud jde o ekonomicky rozvinuté evropské země s polycentrickou sídelní strukturou. Jeho aplikace

\footnotetext{
4 Hodnota 3600 Kč představuje hrubý rozdíl mezi mzdovým průměrem (24303 Kč) a mediánem $(20707$ Kč) v Jihomoravském kraji v roce 2011. Modelový př́íklad vychází z předpokladu, že pro spádovou oblast Brna je relevantní dosažení mzdového mediánu, zatímco pro Brno je relevantní dosažení mzdového průměru (př́íp. nadprůměru). Pokud bychom sledovali nejpravděpodobnější nárůst čistého př́imu pro tuto situaci, pak by zaokrouhlená hodnota odpovídala druhému sloupci tj. $2500 \mathrm{Kč}$.

${ }^{5}$ Hodnota času nebyla $\mathrm{v}$ této analýze uvažována $\mathrm{z}$ důvodu značné variability dané proměnné, při jejímž výpočtu je abstrahováno od řady individuálních charakteristik a výchozích předpokladů (např. zda vyjíždějící pracovník v místě svého bydliště má možnost získat práci či nikoliv, dále zda čas strávený ve veřejné dopravě považuje za smysluplně strávený apod.). Tuto problematičnost lze sledovat např. i ve studii Melichara, Ježka a Pojkarové [6], kteří navrhují hodnotu času stanovovat jako koeficient zjištěný pro EU 25ve studii HEATCO, vážený dle HDP na obyvatele podle parity kupní síly. Tímto způsobem stanovená hodnota času by však pro Jihomoravský kraj v roce 2011 dosahovala cca 1,4 násobku průměrné mzdy, což se jeví jako zcela nelogické.
} 
umožňuje formulovat koncepčně významné závěry, týkající se např. funkční komplexity mikroregionálních center nebo ekonomických souvislostí rozvoje sídelních systémů. Tyto teoreticky a empiricky podložené závěry lze pak účelné využít pro optimalizaci nástrojů regionální/hospodářské politiky. Model však lze využít řešení specifických otázek, např. pro optimalizaci dopravné obsluhy území s využitím konceptu mezní míry výrobních zdrojů. $Z$ provedených analýz mobility pracovních sil vyplývá, že mezní míra této mobility nabývá různých hodnot, odvíjejících se z očekávaného potenciálního zvýšení odpovídajících skutečných výnosů (z pohledu vyjíždějícího jde v podstatě o řešení otázky, jaký by měl být přrirůstek mzdy, aby byla vyjiźd'ka do práce ekonomicky př̀i daných nákladech na dopravu determinovaných vzdálenosti od centra dojižd'ky výhodná). V př́padě Jihomoravského kraje je možné formulovat tezi, že mezní míra mobility nabývá převážně př́znivých hodnot ve spádové oblasti 30 až 40 kilometrů od Brna. Tato vzdálenost koresponduje s př́městskou oblastí Brna vymezenou alespoň $25 \%$ vyjížd'kou ekonomicky aktivních obyvatel za prací do Brna, a do určité míry i s výsledky výzkumů spádových oblastí nákupních center (Kunc, Synková, 2010, Kunc a kol., 2011).

\section{Literatura}

[1] CARSKÝ, J. Podil jednotlivých druhů dopravy na dělbě přepravní práce a vliv délky vykonané cesty na použití dopravního prostředku. Centrum dopravního výzkumu, 2007, $5 \mathrm{~s}$.

[2] ČSÚ. Míra inflace, vývoj spotřebitelských cen vybraných výrobků, 2011.

[3] HAMPL, M. Geografická organizace společnosti v České republice: transformační procesy a jejich obecný kontext. Praha: Karlova univerzita, 2005. 147 s.

[4] IDOS Jizdní rády. Dostupné z: <http://jizdnirady.idnes.cz>.

[5] Integrovaný dopravní systém Jihomoravského kraje. Dostupné z: $<$ http://www.idsjmk.cz $>$.

[6] KUNC, J., SYNKOVÁ, L., Brněnská příměstská oblast: př́iklad jejího vymezení. In Klímová, V. (ed.) $13^{\text {th }}$ International Colloquium on Regional Sciences. Conference proceedings. Brno: Masaryk University, 2010. pp. 284-290.

[7] KUNC, P., TONEV, P. FRANTÁL, B.: Nákupní spád a vybrané nákupní zvyklosti návštěvníků Galerie Vaňkovka. In Klímová, V., Žítek, V. (eds.) $14^{\text {th }}$ International Colloquium on Regional Sciences. Conference proceedings. Brno: Masaryk University, 2011. pp. 47-55.

[8] Mapy Google. Dostupné z: < http://www.maps.google.cz>.

[9] MELICHAR, V., JEŽEK, J., POJKAROVÁ, K.: Ocenění externích účinků a nákladů kongesce. Perner's Contacts, 2008, vol. 3, no. 5, pp. 234-245.

[10] MUlligan, G., PARTRIDGE, M., CARRUTHERS. J.: Central place theory and its reemergence in regional science. Annals of Regional Science, 2012, 48, pp. 405-431.

[11] VITURKA, M., ŽÍTEK, V., KLÍMOVÁ, V., TONEV, P.: Application of Microeconomic and Macroeconomic Approach to Evaluating Disparities in the Regional development. Ekonomický časopis, 2011, 7, s 71-90.

[12] VITURKA, M.: Changes of business environment quality according to Czech regions and administrative districts of MEC in period 2001/2002-2006/2008. In Klímová, V., Žitek, V. (eds.) $14^{\text {th }}$ International Colloquium on Regional Sciences. Conference proceedings. Brno: Masarykova univerzita. pp. 19-24.

[13] VITURKA, M.: New approach to evaluating disparities in the regional development. In Klímová, V. (ed.) $13^{\text {th }}$ International colloquium on regional sciences. Conference proceedings. Brno: Masaryk University, 2010. pp. 16-18. 